\title{
Initiating The Concept of Democracy As Reaffirming In Efforts To Increase Women Capacity In Bureucracy
}

\author{
Amaliatulwalidain \\ Government Studies Program \\ Global Mandiri University \\ Palembang, Indonesia \\ Email: Amaliatulwalidain@gmail.com
}

\begin{abstract}
The Reform Era in $\mathbf{1 9 9 8}$ has marked a shift in the political conditions of a more democratic government from the previous conditions. One of the instruments and targets of the government's political change is to conduct bureaucratic reforms directed to the principles of accountability, responsiveness, efficiency and effectiveness. A series of changes to the bureaucracy not only focus on improvements adapted to these principles, but also improvements in a more populist bureaucratic culture system to the position of women within the bureaucracy. So far, the bureaucratic condition is heavily populated with patriarchal culture and is male dominance that not only creates a gender-neutral working environment but also the understanding of the rules and processes of policy-making that are sometimes gender biased. The bureaucracy also often becomes the arena of the production and reproduction of gender cultural image which gives more privilage to men's gender, because it is undeniable that hiraerki and organizational practice in bureaucracy is more emphasized masculinity aspect, thus indirectly marginalizing women position in bureaucracy . In an attempt to reduce gender biased inequalities in the bureaucracy, in addition to efforts to reduce the very gender biased rules and promote hirarerki and women's friendly women's practices, it is also necessary to have the right ideas and strategies to increase women's capacity in the bureaucracy, through the idea of "Femocrat Concept". In the idea of "Femocrat Concept", the role and position of women is strongly emphasized on empowerment and improving women's effort in intervening bureaucracy in favor of women's issues, interests and policies.
\end{abstract}

Keywords-Femocrat Concept, Position of Women, Bureaucracy

\section{INTRODUCTION}

The political and administrative reform of 1998 is the entry point to a new history in the dynamics of political life and national government, especially in realizing good governance. One important substance of such political reform is "bureaucratic reform", through bureaucratic reform of governance manifested to be an effective and efficient government. In most developing countries that have undergone a transformation in the socio-political, governance and development aspects, bureaucratic reform is the first step and the priority in development which is generally done through two strategies: first, revitalizing the position, the role and the institutional function that becomes the motor of administrative reform, and both reorganize the system of state administration both in terms of structure, process, human resources (civil servants) and relations between state and society (Nyoman Sumaryadi, 2016, p.1).

In line with the bureaucratic reform that emphasizes the strategy of revitalization and administration system, one of the social facts that also emphasizes the importance of a strategy is how to position women in bureaucracy. Often the involvement of women in the bureaucracy is not well represented, the existence of women is always underestimated, thus affecting their roles and capacities in the bureaucracy, especially in the career path. The phenomenon in seeing women's obstacles to achieving a position within the bureaucracy is explicitly revealed by Carol Hymowitz and Timothy D. Schellhardt as the phenomenon of "The Glass Ceiling". (Subono, 2012, p 14)

Glass Ceiling phenomenon can be traced in research conducted by Cakra Wikara Indonesia (CWI) and Knowledge Sector Intiative Indonesia (KSI) since March 2017, the number of female bureaucrats collected from 34 ministries in Indonesia for 2014 to 2016 is still very low, obtained from the State Personnel Board, that the tendency for the presence of female bureaucrats in general will be reduced in the ranks of higher positions. Clearly the analysis is in reverse proportion to the beginning of the presence of female bureaucrats in the event of a CPNS recruitment, in which the presence of women is fairly evenly distributed.

According to Nur Iman Subono, the phenomenon of The Glass Ceiling (Subono, 2012, p.14), generally explains the obstacles of women in the bureaucracy. the reality and the condition of women to reach top and strategic position in pioneering career in bureaucracy become obstructed due to lower motivation of work from within woman because some of factors are, bureaucratic culture factor which is full of masculine culture and internal factor in self-confident woman stuck in the stereotype that women who have a career and occupy a certain position in the bureaucracy will abandon children and families. 
It can not be denied that Indonesia's patriarchal bureaucracy model gives considerable contribution to the glass ceiling phenomenon. In addition, the masculine bureaucratic and mass-friendly character of women has been institutionalized through bureaucratic agendas and policies that are not populist towards women, as well as on political ideas related to women-based interests, the question of why it can happen It can be understood that in addition to the bureaucratic model of Indonesia which is very partriarchy and male domination, on the one hand in practice, maledominated bureaucrats have various policies and authority to implement policies.

The condition is also revealed by Max Weber, in fact the bureaucrats serve a very important role in the democratic system because of the regular, impersonal and uniform bureaucratic character of policy, but at the same time they behave and behave in anti-democracy because they have the discretion to exercise their authority even though they are not elected by elections, and therefore they are not directly accountable to the public. (Subono, 2012, p.15)

Discussion on women's involvement in bureaucratic structures relates to the access of women bureaucrats in formulating various interests and policies apart from inseparable from the glass ceiling constraints, social constraints and structures they must face within the bureaucracy. Their low capacity is directly proportional to their potential, especially to represent the interests of women. of these conditions clearly provide an objective picture of the role of female bureaucrats in bureaucratic structures as if they did not give any meaning whatsoever regarding their existence in the bureaucracy.

The imbalance between the position of female bureaucrats and male bureaucrats in bureaucratic structures in Indonesia is clearly a significant constraint, especially in the process of reforming the bureaucracy to make room for women, at least at the level of practice not just the policy foundation used to reduce the constraints. What is more important in identifying the problem with the need to change the mindset of the bureaucrats of women, that their representation in the bureaucracy is also closely related to the individual interests of women they represent, thus their (bureaucratized) presence becomes more meaningful, because they represent the interests of women they represent.

\section{DISCUSSION}

\section{A. The Position of Women and Bureaucracy: Feminist Criticism of the Weberian Bureaucracy}

It is undeniable that between political values in society and bureaucracy are closely linked. Both clearly provide a significant influence in shaping the culture and character of life within the social structure of society. The close link between political values and bureaucracy can be traced back to the beginning of the bureaucracy itself in the 18th century, in the French dictionary of 1798 defining bureaucracy as "the power, the influence of the leaders and the staff of the governmental bureau." While the 1813 edition of the German dictionary defines bureaucracy as "the authority or power by which the departments of government and its branches seize it from citizens to themselves". (Cornelis Lay, 1997, p 24-25).

The early presence of the bureaucracy as part of carrying out government functions with the aim of maintaining authority and power clearly does not include women's elements and interests as part of the initial concept of bureaucracy. When explored from various perspectives on the initial concept of bureaucracy, from a number of classical thinkers such as Gaetano Mosca, Robert Michels and Max Weber, the presence of bureaucracy is heavily loaded with highly patriarchal political and power elements.

According to Michels' idea, bureaucracy is a necessity for every modern country. In his Political Parties (1911) he explains that the modern state needs a great bureaucracy because through it the dominant political class guarantees their dominance. Another thing according to Gaetano Mosca, bureaucracy is the dominant class in politics, in his The Rulling Class (1985) the ruling class not only governs by using brute force, but also justifies their power through political formulations with abstract principles, with specialization several functions of government separately and become an exclusive power that controls each part. Meanwhile, according to Max Weber, widely known as a modern bureaucratic idea-maker, the emergence of modern countries, accompanied by modernization in social and economic fields has resulted in widespread functions that governments must undertake if they wish to rule (Cornelis Lay, 1997, p 24-25).

Bureaucratic perspective according to the classical thinkers, then developed and became a choice in various countries, especially on the evaluation of the bureaucratic thinking of Max Weber. Referring to the experience of European countries, including in Indonesia, the bureaucracy is not only regarded as an actor who simply executes government administration and various policies and regulations outside himself, but also the bureaucracy becomes "in power" and monopolizes the socio-political life of its people (Subono, 2012, p.11).

In short, the bureaucracy is an all-powerful actor, on the basis of which is also then much criticism of the bureaucracy that is considered in practice not gender-neutral and value-free. There are interests of community groups who are more benefited with the presence of bureaucracy, more specifically, bureaucracy is a battle arena of gender relations between men and women, which is a partial society, while women, children, and other marginal groups are parties who are often harmed by the operation of such bureaucratic machinery (Subono, 2012, p.12). Moreover, according to Lay, (Cornelis Lay, 1997, p 43) of bureaucracy in Indonesia under conditions of feudal Indonesian society structure, where the status of bureaucratic power is in high social status, government officials enjoy high social status and therefore they have great and unparalleled power, especially within the bureaucratic structure.

According to Rosabeth Kanter Moss (Moss, 1977, p. 92) cited by Acker (1990, p.143) the elimination of women in bureaucratic structures is the result of rational and bureaucratic reasoning built into "masculine ethics". 
Masculine ethics then proceeds to determine the typical image of the ideal type of person occupies them (read: bureaucracy) especially the male nature as the need for effective bureaucracy, dexterity in the face of the problem, the analytical ability of the planned personal and emotional considerations for the benefit of the attainment of the task, cognitive in problem solving and decision making.

A very patriarchal bureaucratic condition like that, then got criticism from Kathy. E. Ferguson (Ferguson, 1984) who saw bureaucracy as the construction of male domination, where the early bureaucracy in the early discourse had failed to put gender in the analysis of power, the result of bureaucracy emerged without body and not gender neutral. The emergence of a new vision of the bureaucracy on gender on the one hand only makes gender as an analogy, not as a component, so the bureaucracy, according to him, is an organization full of men and oppressors.

The masculine bureaucratic ethic, ultimately becomes the determinant as well as the main factor in determining the positions, opportunities and opportunities of women to gain employment and career in bureaucratic structure. Women's access, positions and opportunities become limited, since the bureaucratic structure from the beginning of its creation has discriminated against the belief that male characteristics are more appropriate for the type of work within the bureaucracy than women.

In response to these conditions, according to Doroty Smith (1979, p.148) quoted by Joan Acker, states that a fairness, if the workings of the bureaucracy are based not only on the world of work and gender relations that are not gender-neutral but also because of interference hands and participation of the ruling "apparatus" in a society that deliberately develops a managerial system for organizational efficiency that does not presuppose women as subjects.

The criticism of Joan Acker (1990, p.40) further confirms that bureaucracy is an entirely gender neutral organization, in which the bureaucratic process of gender and sexuality is obscured through asexual discourse as a form of control within the bureaucracy. Basically bureaucracy is very full of aspects of masculinity that envelop bureaucratic processes and marginalize women and contribute to the maintenance of gender segregation within the organization.

Therefore, according to Lovenduski (Joni Lovenduski, 2005, p.63), bureaucracy as an organization in its development has received much criticism from feminists, feminists argue that women are entitled to its place in the world of formal politics as well as in bureaucracy, however must be constructed. Some arguments require that institutional change be followed by the fulfillment and inclusion of women in bureaucratic structures and the argument that women themselves should be able to construct the separation of public spaces and private spaces as potentially hampering.

\section{B. Bureaucracy in Indonesia: Reality of "Presence" of Women in Bureaucracy}

The demands of bureaucratic reform in Indonesia after the collapse of the New Order, in fact did not change the condition and position of women in the bureaucracy structure in
Indonesia. The number of female bureaucrats in the bureaucracy in Indonesia can be said to be apprehensive. Based on a recent study from CWI (Cakra Wirawa Indonesia) who conducted research in 34 ministries in Indonesia in the period 2014-2016 obtained from the data of State Personnel Board (BKN). The research was conducted by analyzing the interpretation of the regulation of the Civil Service Act until the State Civil Apparatus Act 2014, along with other regulations, finding the conclusion that the gender imbalance in bureaucracy in Indonesia is still significant today. It can be seen from the following table:

Composition of Echelon and Non Echelon Civil Servants in Ministries 2014-2016

\begin{tabular}{|l|l|l|l|l|}
\hline Tahun & $\begin{array}{l}\text { \% PNS } \\
\text { non eselon } \\
\text { laki-laki }\end{array}$ & $\begin{array}{l}\text { \% PNS non } \\
\text { eselon } \\
\text { perempuan }\end{array}$ & $\begin{array}{l}\text { \% PNS } \\
\text { eselon } \\
\text { laki-laki }\end{array}$ & $\begin{array}{l}\text { \% PNS } \\
\text { eselon } \\
\text { perempuan }\end{array}$ \\
\hline 2014 & 61.66 & 38.34 & 77.41 & 22.59 \\
\hline 2015 & 59.90 & 40.10 & 77.94 & 22.06 \\
\hline 2016 & 59.44 & 40.56 & 74.21 & 25.79 \\
\hline
\end{tabular}

Sumber: (http://cakrawikara.id/2017)

The exposure of data presented by CWI at the Indonesia Develompment Forum event in March 2017 (indonesiadevelompentforum.com), provides a complete picture that the gender imbalance that occurs in the bureaucracy structure in Indonesia is still massive. In particular, the gender imbalances that occur are identified from the 4 patterns of gender inequality distribution in the ministry / institution bureaucracy (http://cakrawikara.id/2017). First Pattern, civil servant recruitment has been proportionate on the basis of gender and so is promotion promotion. Second pattern, civil servant recruitment has been proportionate based on gender, but in promotion there is still imbalance. Third Pattern, recruitment of unequal civil servants by gender, but promotion positions meet proportionality by gender. Fourth Pattern, both in recruitment and promotion of position happened inequality of gender distribution. Despite this diversity of patterns in a number of ministries, there is generally a low number of fembale civil servants in high positions at 34 ministries.

The same research, previously also been done by Puskapol UI (Center for Political Science Studies UI) in 34 ministries in 2014, where the results concluded that functionally, the number of civil servants in 34 ministries totaling 503,554 people divided into 205,951 attendance bureaucrats (PNS) of women or $(40.9 \%)$ is proportionally equal to the number of male bureaucrats $(297,603)(59.1 \%)$. But the same thing does not happen in structural positions in 34 ministries, where the composition of structural positions dominated by men as much $(77,62 \%)$, the rest $(22,38 \%)$ filled by women. Of the total number of civil servants as much as 503,554 . can be said from the total number of civil servants in 34 ministries, only 29,221 people or equivalent $(5.8 \%)$ who have structural (echelon) positions. (http://www.puskapol.ui.ac.id). When reflecting on the condition and description of the position of female bureaucrats in the bureaucracy structure in Indonesia, it really 
does not differ much from the picture of women's position in bureaucratic structures in developed countries, as in Virginia which is one of the states in the United States. From the research of Velma J. Ballard (Velma J. Ballard, 2015, p.27) that of the ten departments of government in Virginia dominated more by men. The total number of employees from ten Virginia government departments is 916 people, women are only in composition (7\%) only.

Viewed from the results of the research that has been done in observing the condition and position of women and bureaucratic structures in Indonesia, it can be concluded according to Mayling-Oey quoted by Sri Yuliani (Sri Yuliani, 2004, p.3), that the bureaucrat staffing structure to form "theory rhombus ", ie small at the top and bottom, but widened ketengah. The higher the group, the lower the number of female bureaucrats.

\section{Initiating the Femocrat Concept as Refarming in Efforts to Increase Women's Capacity in Bureaucracy}

The growing awareness of gender inequalities in the bureaucracy has triggered an important analysis especially around the 1990s to examine more deeply about gender differences in bureaucratic structures using feminist perspectives. The use of feminist perspectives in solving the problem of gender inequality and injustice in the bureaucracy is inseparable from the fact that the increasing number of women becoming bureaucrats and triggered by the growing demand for respect for human rights and democratic values. (Sri Yuliani, 2004, p.1)

Moreover, in 1994, not a few of the women entered the bureaucratic structure, but also entered the political institutional arena both in the legislature and in the executive and senate where they reside, with the aim of continuing the struggle for women's equality. Their struggle began to shift away from the struggle of civil society through the activities of the women's movement by tearing into political inclusion activities as a way of dealing with state structures in an attempt to redefine strategy and to create gender equality, especially in formal political institutions (Amanda Gouws 1996, p 31).

One of the strategies then elaborated in addressing the solution of gender inequality within the bureaucracy through an analysis of the substantive involvement of female bureaucrats in bureaucratic structures known as bureaucratic representation strategies, through bureaucratic representation strategies, women are not only considered to be present only in the bureaucracy, but also their most important come coloring it (Subono, 2012, p.16). The notion that women bureaucrats are not just "present" in the bureaucratic structure, is also based on the belief that bureaucracy is also a 'representative place' for all social problems especially related to women's issues and interests.

The central theme of bureaucracy as a representative place according to Meier \& Jill. N. Crotty (Kenneth J. Meier \&Jill Nicholson Crotty, 2006, p.851) is based on the assumption that female bureaucrats can also reflect the demographic origin, segments and community groups that are represented and then translated and manifested in policy programs as well as decisions favorable to segments communities represented by showing the same demographic origin and values.

The similarity of shared values and the same demographic origin will certainly direct the female bureaucrats to act actively and deliberately on behalf of the group or segment of the community they represent especially segments and groups of women, from which this process ultimately directs the bureaucrats to their active representation activities in bureaucracy. According to Meier and Stewart (Kenneth J. Meier \& Jill Nicholson Crotty, 2006, p.851) there are three important prerequisites necessary to maximize representative bureaucratic conditions for women. First, the public administrator must have discretion in decision-making and policy implementation processes. Secondly, these bureaucrats must exercise this policy in areas of policy that have important implications for the groups they represent. Third, ensuring that decisions and policies are directly related to the demographics, groups and segments of society they represent.

Specifically, Frederick Mosher (1968) quoted by Nur Iman Subono (Subono, 2012, p.15) distinguishes two important "meanings" of bureaucratic representation, namely passive bureaucracy and active bureaucracy. The first, "passive representation," relates to the source of origin, the individuals in the bureaucracy, and the extent to which they are collectively part of society in general. While "active representation" relates to individuals who are expected to insist the interests, demands and aspirations of those they represent, whether they are the whole society or part of the segment of society.

Further Meier \& Jill. N. Crotty (Kenneth J. Meier \& Jill Nicholson Crotty, 2006, p. 195) says that the theory of passive and active representation illustrates the importance of government bureaucracy with a diverse and representative composition. If women's bureaucrats improve their quality and resources, it is not impossible that these women bureaucrats can improve the policies targeted to their demographic groups, so that the policies and decisions made can affect the access to social and political forces of the groups they represent in the bureaucracy

Let's say that women bureaucrats sitting in bureaucratic structures recognize that their representation in the bureaucracy is aimed at promoting women's agenda of interest, so that various regulations and policies can deal directly with and benefit women's lives through the development of "gender mainstreaming" values ) in their work was bureaucratized as a female bureaucrat. Under these conditions, the awareness of female bureaucrats in constructing mainstreaming gender values according to Amanda Gouws (Amanda Gouws, 1996, p.33) is a fusion of the concept of 'femocrat'. Amanda Gouws mentions that the concept of femocrat is a combination of female (female) with bureaucrat (bureaucrat) which is in bureaucratic structure and have awareness to focus on issues and issues of women. While other terms of the concept of 'femocrat' according to Louise Chappell (2002, p.86) are referring to the definition of the entry of feminist perspectives in all areas of government as an attempt to influence the public policy making explicit by 
focusing on two factors: First, femocrats (each female bureaucrat) can achieve the institutionalized position of the bureaucracy. Second, the extent to which femocrats can apply gender analysis to public policy making.

The reconstruction of gender mainstreaming values (Subono, 2012, p.16) by female bureaucrats or 'femocrats', especially in dealing with women's issues systematically and rationally can be done with several stages of female bureaucratic involvement in the policy-making process, which includes: formation, deliberation, legislation, implementation, and evaluation. Hester Eisentein (1991) quoted in (Subono, 2012, p.17) a professor of sociology at Queens College, proposed three categories of women's intervention in the bureaucracy, among them:

1) 'Bureaucratic-individual' interventions: women enter the government bureaucracy in policy-making levels as a selfidentified feminist. This is how we increase the number of female individuals to enter the bureaucracy. But at the same time, it relates to how we at the same time promote women's individuals into femocrats who are concerned, taking sides and striving for women's issues; in short, women are not only present, but women also color and even determine various policies on issues of issues and solutions about women.

2) 'Bureaucratic-structural' interventions: women create new structures in government or administration designed to benefit women, both in terms of empowerment, participation and friendly women policy. These interventions at both the national and local levels. Hence then we see the establishment of various institutions or bureaus within the organization. We are then familiar with various bureaus, programs, and organizations such as the Women's Empowerment Bureau, Women's Studies Program, or the Ministry of Women's Empowerment.

3) Other forms of feminist political intervention such as 'legal reform' through legislative changes, political participation in leadership roles, present themselves as feminist (selfproclaimed feminist) in trade unions and political parties, and in 'alternative structures' (alternative structure) where feminists build independent organizations outside the existing political and administrative structures.

One example of the success of a femocrat strategy in gender mainstreaming, takes place within the bureaucratic structure in Australia. According to Luise Chappell (Chappell, 2002, p.85) the success of femocrats in Australia is due to the collaboration with progressive labor parties and the structures of the federal state that provide an opportunity for feminist bureaucrats (femocrats) in the arena of parliament in transforming the values of mainstreaming gender into gendersensitive public policies and services. Australian femocrats structurally since 1974 successfully institutionalized the results of gender-sensitive policies, as evidenced by the establishment of the Office of the Status of Women (OSW) spread across several central government departments in each state.

\section{CONCLUSIONS}

During this time the condition of female bureaucrats in the bureaucracy is always in a condition that is marginal and discriminatory. Almost the majority of women always have difficulty especially in taking and obtaining high position in bureaucracy structure. A strong bureaucratic arena with patriarchal culture and male domination significantly contributes greatly to the inhibition of thought processes and the development of self-potential for women's presence within the bureaucracy.

As a result of this condition, there is practically gender inequality and injustice in the bureaucracy which is seen from the lack of representation of the number of women in the bureaucracy, the correlation of the lack of representation of women in the bureaucratic structure also gives a very important influence for the creation of conditions so that the interests of women and other social interests can be well represented.

From the dilemma, then came the understanding that the good and ideal bureaucracy in democracy, is a bureaucracy that put forward the idea on the concept of equality and equality, thus creating a representative bureaucratic conditions, especially in addressing various social problems, including women's issues. Through this understanding, the femoral strategy exists to provide a theoretical framework for the importance of women not only to be present in the bureaucratic structure, but also to eliminate discrimination and marginalization in bureaucratic structures.

The idea of a 'femocrat' which is a combination of the concept of female and bureaucrats is a new strategy in pursuing and constructing the values of gender mainstreaming in order to be well institutionalized within the bureaucratic structure. Not only that, the idea of femocrat is also a theoretical reference which aims to provide understanding and awareness among women bureaucrats in bureaucratic structures to reinforce their roles and positions as representations of the interests of women, expected through their positions and roles as bureaucrats of women, can be a good arena in generating policies and regulations that are more aligned to women's interests effectively, responsively and legitimately.

\section{REFERENCES}

[1] Acker, John. Hierarchies, Jobs, Bodies: A Theory of Gendered Organizations. Gender and Society, Vol. 4, No. 2, Jun., 1990): Sage Publications. This article retrieved from http://www.jstor.org/stable/189609, 1990.

[2] Ballar, J. Velma, Gender and Representative Bureaucracy: The Career Progression of Women Managers in Male- Dominated Occupations in State Government. Dissertation Virginia Commonwealth University Richmond: Virginia, 2015.

[3] Chappell, Louise. The 'F emocrat' Strategy Expanding the Repertoire of Feminist Activists. Hansard Society for Parlianmentary Government, 2002. 
[4] Ferguson, Kathy E. The Feminist Case Against Bureaucracy. Philadelphia: Temple University Press, 1984.

[5] Gouws, Amanda, The Rise of the Femocrat Agenda: Empowering women for gender equity. This article retreived from http://dx.doi.org/10.1080/10130950.1996.9675543, 1996.

[6] Lay, Cornelis, Birokrasi Indonesia. Dalam Kumpulan Tulisan "FungsiFungsi Pemerintahan". Jakarta: Badan Pendidikan dan Pelatihan Departemen Dalam Negeri, 1997.

[7] Lovenduski, Joni, Politik Berparas Perempuan,Yogyakarta : Kanisius, 2005.

[8] Meier.J. Kennet \& Jill. Nicholson Crotty. Gender, Representative Bureaucracy, and Law Enforcement: The Case of Sexual Assault. Essays on Equity, Gender, and Diversity in Public Administration Review, 2006.

[9] Sumaryadi, Nyoman. 2016. Reformasi Birokrasi Pemerintahan Menuju TataKelola Pemerintahan Yang Baik, Bogor: Ghalia Press, 2016, hlm 1

[10] Subono, Nur Imam. Femocrat: Kritik Feminis dan Representasi Birokrasi. Jakarta: Jurnal Perempuan Vol.17 No.4, 2012.

[11] Yuliani, Sri, Pengembangan Karier Perempuan di Birokrasi Publik: Tinjauan dari Perspektif Gender. This article retrieved from sriyuliani.staff.fisip.uns.ac.id/wp-content/uploads/.../Feminisperspektif2-revisi.pdf , 2004.

[12] http://cakrawikara.id/2017/05/paparan-awal-riset-gender-dan-birokrasiketimpangan-gender-di-34-kementerian/, diakses pada hari Selasa, 19 September 2017, Jam $8.28 \mathrm{Wib}$

[13] http://www.puskapol.ui.ac.id/wp-content/uploads/2014/04/factsheetketimpangan-keterwakilan-perempuan-dalam-birokrasi.pdf 